\title{
EFEKTIVITAS LAYANAN BIMBINGAN KELOIMPOK DENGAN PERIMAINAN TRADISIONAL (GOBAK SODOR) UNTUK MENINGKATKAN INTERAKSI SOSIAL PESERTA DIDIK KELAS IV-A DI SD NEGERI 1 KALAIMPANGAN
}

\section{The Effectiveness Of Groups Conselvation Services Using Self Instruction Techniques To Reduce Students 'Social Preliminary In SMA 2 Palangka Raya}

\author{
'Siti Aminah, ${ }^{2}$ Sonedi \\ IUniversitas Muhammadiyah Palangkaraya, Jekan Raya, Palangka Raya, Kalimantan Tengah, Indonesia \\ 2 Universitas Muhammadiyah Palangkaraya, Jekan Raya, Palangka Raya, Kalimantan Tengah, Indonesia
}

\section{ARTIKEL INFO}

Diterima

Juni 2018

Dipublikasi

Agustus 2018

*E-mail:

sonedibadli@gmail.com

Orchid:

\begin{abstract}
Penelitian ini bertujuan untuk : (I) Mengetahui profil intetaksi sosial peserta didik kelas IV-A di SD Negeri I Kalampangan, (2) Mengetahui efektivitas bimbingan kelompok dengan permainan tradisional (gobak sodor) untuk meningkatkan interaksi sosial peserta didik kelas IV-A di SD Negeri I Kalampangan. Populasi penelitian ini adalah seluruh peserta didik kelas IV-A di SD Negeri I Kalampangan sebanyak 21 orang peserta didik dan dan 15 orang peserta didik yang dijadikan sebagai sampel penelitian. Metode yang digunakan adalah eksperimen, dengan eksperimen Pre-Post Design yaitu analisis dengan melibatkan dua pengukuran pada subjek yang sama terhadap suatu pengaruh atau perlakuan tertentu. Teknik pengumpulan data dalam penelitian ini menggunakan observasi dan skala. Hasil penelitian ini menunjukkan bahwa : (I) Tingkat interaksi sosial peserta didik kelas IV-A di SD Negeri I Kalampangan brdasarkan hasil dari uji Paired Sample T-Test menunjukkan bahwa perilaku interaksi sosial mengalami peningkatan rata-rata awal 40,10 (2) setelah diberikan treatment (perlakuan) menjadi dengan jumlah peningkatan rata-rata sebesar 72,50 dengan jumlah rata-rata peningkatan sebesar 30, (3) Artinya "Layanan bimbingan kelompok dengan permainan tradisional (gobak sodor) dapat meningkatkan interaksi sosial peserta didik kelas IV-A di SD Negeri I Kalampangan.
\end{abstract}

Kata kunci: Bimbingan Kelompok, Permainan Tradisional (Gobak Sodor) Interaksi Sosial

\begin{abstract}
This study aims to: (I) Know the social interaction profile of IV-A students in SD Negeri I Kalampangan, (2) Know the effectiveness of group guidance with traditional games (gobak sodor) to improve social interaction of IV-A students in elementary school Negeri I Kalampangan. The study population was 2 I IV-A students in SD Negeri I Kalampangan with 21 students and 15 students as the research sample. The method used is an experiment, with the Pre-Post Design experiment that is analysis involving two measurements on the same subject against a particular influence or treatment. Data collection techniques in this study used observation and scale. The results of this study indicate that: (I) The level of social interaction of IV-A class students in SD Negeri I The results based on the results of the Paired Sample T-Test showed that social interaction behavior had an initial increase of 40.10 (2) after given treatment (treatment) to the number of increases on average by 72.50 with an average number of increases of 30, (3) Meaning "Group guidance services with traditional games (gobak sodor) can increase social interaction of IV-A class students at SD Negeri I Kalampangan.
\end{abstract}

Keywords: Group Guidance, Traditional Games (Gobak Sodor) Social Interaction 


\section{PENDAHULUAN}

Manusia secara hakiki merupakan makhluk sosial, dimana ia dituntut untuk melakukan hubungan sosial antar sesama dalam hidupnya. Hubungan sosial itu merupakan salah satu hubungan yang harus dilaksanakan, mengandung pengertian bahwa dalan hubungan itu setiap individu menyadari tentang kehadirannya di samping kehadiran individu lain. Manusia membutuhkan pergaulan dengan orang lain untuk memenuhi kebutuhan biologisnya seperti makan, minum, dan sebagainya. Oleh sebab itu manusia disebut sebagai makhluk sosial.

Menurut Walgito (Faishal, dkk20|4:105) menegaskan bahwa interaksi sosial adalah hubungan antara individu satu dengan individu yang lain yang saling memengaruhi dan terdapat hubungan saling timbal balik.

Berdasarkan fenomena yang ada pada peserta didik kelas IV-A SD Negeri I Kalampangan, terdapat peserta didik yang cenderung kurang berinteraksi dengan teman, seperti: terdapat peserta didik yang cenderung lebih memilih bermain dengan gadgetnya di banding bermain dengan teman, masih terdapat peserta didik yang memilihmilih teman, terdapat peserta didik yang menyendiri, terdapat peserta didik yang cenderung menolak di kelompokkan, terdapat peserta didik yang cenderung kurang berinteraksi dengan teman dan terdapat peserta didik yang cenderung suka berdiam diri dari pada berkumpul dengan teman. Sehingga peserta didik cenderung kurang berinteraksi dengan teman. Adapun penyebab interaksi sosial rendah salah satunya yaitu game online bisa menyebabkan seseorang mengacuhkan lingkungan sekitar tanpa menyadarinya.

Menurut SK Mendikbud No. 025/O/I995 (Latifaty, Ismy, 2013: 2) Bimbingan dan konseling adalah pelayanan bantuan untuk peserta didik, baik secara perorangan maupun kelompok, agar mandiri dan berkembang secara optimal, dalam bimbingan pribadi, bimbingan sosial, bimbingan belajar dan bimbingan karier, melalui berbagai jenis layanan dan kegiatan pendukung berdasarkan norma-norma yang berlaku.

\section{METODE PENELITIAN}

Metode yang digunakan dalam penelitian ini adalah pre-eksperimental design. Menurut Emzir ( 2010: 96 )" mengapa dinamakan pre-eksperimental design karena mengikuti langkah-langkah dasar eksperimental tetapi gagal memasuki kelompok kontrol". Dengan kata lain kelompok tunggal sering diteliti, tetapi tidak ada perbandingan dengan kelompok nonperlakuan dibuat. Sedangkan jenis penelitian yang digunakan adalah one group pre tes post test.

Bentuk Pre-Experimental yang digunakan adalah One-Group Pretest-Postes Design ( Satu kelompok Prates-Postes).Pada desain ini terdapat pretest sebelum diberi perlakuan, dengan demikian hasil perlakuan dapat diketahui lebih akurat karena dapat membndigkan keadaan sebelum dengan sesudah diberikan perlakuan. Menurut Sugiyono (2012:III) rancangan dapat digambarkan sebagai berikut:

Keterangan :

I. OI, yaitu pretes yang digunakan untuk mengukur pemahman awal mengenai interaksi sosial peserta didik sebelum diberikan layanan bimbingan kelompok dengan Permainan Tradisional (gobak sodor).

2. $X$, yaitu treatment pemberian perlakuan atau layanan bimbingan kelompok dengan.Permainan Tradisional (gobak sodor). Pemberian treatment dilakukan dengan 8 kali sesi pertemuan yang mana setiap sesinya akan diobservasi oleh peneliti.

3. O2, yaitu yang digunakan untuk mengatur pemahaman peserta didik tentang 
Jurnal Bimbingan dan Konseling

interaksi sosial sesudah diberikan layanan bimbingan kelompok kelompok dengan Permainan Tradisional (gobak sodor).

\section{HASIL DAN PEMBAHASAN}

Sebelum peneliti menggunakan permainan tradisional (gobak sodor) untuk meningkatkan interaksi sosial, maka peneliti terlebih dahulu melakukan pre-test (tes awal) kepada peserta didik kelas IV-A dengan jumlah peserta didik 10 orang yaitu 5 laki-laki dan 5 perempuan. Setelah peneliti melakukan pre-test (tes awal), peneliti melakukan treatment sebanyak 6 kali dengan permainan tradisional (gobak sodor), lalu peneliti melanjutkan kembali dengan melakukan post test (tes akhir).

Perbandingan hasil pretest dan post-test

Adapun hasil perbandingan dapat dilihat dari gambar perbandingan skor pretest dan post-test anggota kelompok setelah mengikuti kegiatan layanan bimbingan kelompok.

\section{Gambar I}

Perbandingan hasil pretest dan pos-test interaksi sosial

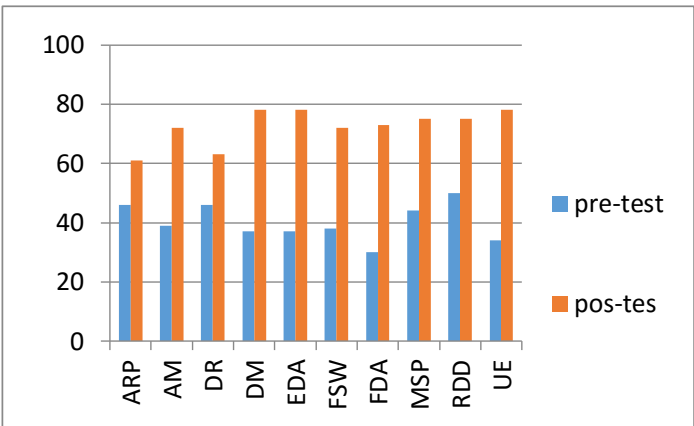

Berdasarkan gambar di atas dapat dilihat bahwa interaksi sosial peserta didik setelah mengikuti kegiatan layanan bimbingan kelompok dengan permainan tradisional (gobak sodor) mengalami peningkatan yaitu skor post-test lebih tinggi dari skor pre test karena hasil tersebut dilaksanakan dengan sugguh-sungguh sesuai dengan prosedur yang di rencanakan.

Uji efektifitas bimbingan kelompok dengan permainan tradisional (gobak sodor) untuk meningkatkan interaksi sosial pada peserta didik dianalisis dengan statistik PairedSample T-Test.

Layanan bimbingan kelompok dengan permainan tradisional (gobak sodor) dapat dikatakan meningkatkan interaksi sosial pada peserta didik kelas IV-A di SD Negeri I Kalampangan Tahun Ajaran 2017/20I8.

jika terjadi peningkatan rata-rata hasil pre-test dan post-test.

Penghitungan menggunakan SPSS
20.00. hasil penghitungan dengan
menggunakan aplikasi SPSS 20.00 disajikan
dalam tabel sebagai berikut:

Tabel I

Paired Samples Statistics

\begin{tabular}{cccc}
\hline Mean & $\mathrm{N}$ & $\begin{array}{l}\text { Std. } \\
\text { Deviation }\end{array}$ & $\begin{array}{l}\text { Std. Error } \\
\text { Mean }\end{array}$ \\
\hline 40,10 & 10 & 6,208 & 1,963 \\
72,50 & 10 & 6,023 & 1,905 \\
\hline Tabel & Paried Samples Statistic & menunjukkan
\end{tabular}
bahwa perilaku mengalami mengalami peningkatan rata-rata awal 40,10 menjadi dengan jumlah rata-rata peningkatan sebesar 72,50 .

\section{KESIMPULAN}

Berdasarkan dari hasil penelitian dan pembahasan yang dilakukan dan diperoleh oleh peneliti selama kegiatan penelitian, maka peneliti dapat menjabarkan beberapa kesimpulan yaitu:

I. Tingkat interaksi sosial peserta didik kelas IV-A di SD Negeri I Kalampangan sebelum menggunakan permainan tradisional (gobak sodor) di dasarkan pada hasil Uji Paired Sample $T$ Test menunjukkan bahwa perilaku interaksi sosial yaitu sebesar 40,10 .

2. Tingkat interaksi sosial peserta didik kelas IV-A di SD Negeri I Kalampangan setelah menggunakan permainan tradisional (gobak sodor) mengalami peningkatan yaitu sebesar 72,50 . 
Jurnal Bimbingan dan Konseling

3. Bimbingan kelompok dengan permainan tradisional (gobak sodor) efektif dalam meningkatkan interaksi sosial peserta didik kelas IV-A di SD Negeri I Kalampangan dengan diperoleh peningkatan skor dari 10 peserta didik yang menjadi subjek penelitian. $\mathrm{Hal}$ ini terbukti dari hasil analisis uji Paired Sample T-Test yang menunjukkan bahwa kesepuluh peserta didik pada subjek penelitian mengalami peningkatan tingkat perilaku interaksi sosial sebelum dilakukan treatment (perlakuan) dan sesudah dilakukan treatment (perlakuan).

\section{DAFTAR PUSTAKA}

Emzir.(2010).Metodologi Penelitian Kuantitatif dan Kualitatif.Jakarta:PT Raja Grafindo Persada

Faishal,Dkk.20I4. Meningkatkan Interaksi

Sosial Melalui Layanan Penguasaan

Konten Dengan Media Puzzle Pada

Siswa Kelas $X$ Sma Negeri I

Semarangtahun Pelajaran

2014/2015.Jurnal Pendidikan Dasar.ISSN 2406-8691

Sugiyono,2013, Metode Penelitian pendidikan, Bandung: Alfabeta

Sugiyono. (2012). Metode Penelitian Kombinasi (Mixed Method). Bandung: C.V Alfabeta 